\title{
РОЛЬ ВИЗНАЧЕННЯ \\ ГЛІКОЗИЛЬОВАНОГО ГЕМОГЛОБІНУ У ПАЦІЄНТІВ З МОЗКОВИМ ІНСУЛЬТОМ
}

\author{
Фломін Ю. В. ${ }^{1}$, Гур'янов В. Г. ${ }^{2}$, Соколова Л. К. ${ }^{3}$, \\ Таран Л. Ф. ${ }^{1}$, Соколова Л. І. ${ }^{2}$ \\ ${ }^{1}$ Медичний центр «Універсальна клініка «Оберіг», \\ м. Київ, Украӥна; \\ ${ }^{2}$ Національний медичний університет ім. О. О. Богомольия МОЗ Украӥни, \\ м. Київ, Україна; \\ ${ }^{3}$ Інститут ендокринологї та обміну речовин і.м. В. П. Колісаренка НАМН Украӥни, \\ м. Київ, Украӥна \\ flomin.yuriy@gmail.com
}

Неінфекційні захворювання, зокрема мозковий інсульт (MI) та цукровий діабет (ЦД), е провідної причиною смерті та обмежень життедіяльності населення більшості країн, і їх тягар продовжуе зростати. Якщо сучасні тенденції істотно не зміняться, вже на початку другої половини XXI сторіччя у світі щороку буде спостерігатися близько 30 млн. МІ та 12 млн. смертей внаслідок МI, а число людей, які перенесли МI, сягне 200 млн. Такий розвиток подій створить серйозну загрозу для систем охорони здоров'я більшості країн, але цієї кризи можна уникнути, оскільки значна частина цього тягаря обумовлена впливом факторів ризику, які піддаються корекції [1]. Розповсюдженість ЦД стрімко зростає: у 2019 році у світі було близько 463 млн. осіб з ЦД, а до 2045 року їх число перевищить 700 млн. [2]. Взаємозв'язок між МI та ЦД є багатогранним, адже ЦД $е$ як загальновизнаним фактором ризику МI, так і супутнім захворюванням у значної частини паціентів, що перенесли МI [3, 4]. В цілому, захворюваність на МІ у пацієнтів з ЦД е 1,5-2 рази вищою, ніж у їх однолітків без ЦД. У паціентів з ЦД підвищений ризик як ішемічного МI, так і внутрішньомозкового крововиливу (ВМК) [5]. У низці досліджень було продемонстровано, що ЦД у паціентів з МI асоціюеться з вищим ризиком смерті та ускладнень, більшою тривалістю перебування в стаціонарі та гіршим функціональним результатом лікування

* Дослідження проведене в рамках науково-дослідної роботи «Визначення особливостей перебігу та наслідків інсульту у хворих різних вікових груп з урахуванням генетичних та інфекційних чинників і коморбідної патології» (державний реєстраційний № 0118U003695).

Установою, що фінансуе дослідження, е МОЗ України.

Автори гарантують повну відповідальність за все, що опубліковано в статті.

Автори гарантують відсутність конфлікту інтересів і власної фінансової зацікавленості при виконанні роботи та написанні статті.

Рукопис надійшов до редакції 30.08.2020. 
[6]. Проте в інших дослідженнях не було виявлено значущих відмінностей у результатах лікування MI між пацієнтам з ЦД та без ЦД [7].

Існує великий обсяг даних, які свідчать, що значна гіперглікемія у ранньому періоді МI асоціюється 3 несприятливим прогнозом [5, 8]. Інші групи взагалі не виявили зв’язку між гіперглікемією та фрункціональним станом при ішемічному МI [9]. Насправді, гіперглікемія як прояв стресової реакції при гострому MI не є сталим явищем, тому деякі дослідники наголошують на більш важливій прогностичній ролі хронічної гіперглікемії [6]. На відміну від вимірювання концентрації глюкози у крові натщесерце, на який може впливати багато чинників, дослідження рівня глікозильованого гемоглобіну (HbA1c) дає уяв- лення про глікемію протягом попередніх 90-120 днів, що дозволяе діагностувати ЦД незалежно від наявності «стресової» гіперглікемії [10]. Дослідження НbA1с виконується однократно і незалежно від прийому їжі, що робить його зручним для використання у клінічній практиці [11]. Відповідно, дослідження рівня HbA1c може використовуватись для виявлення ЦД або предіабету та поліпшення контролю глікемії у пацієнтів з MI [12]. Проте роль визначення рівня HbA1c при МI ще однозначно не визначена [9].

Мета дослідження: вивчити можливість та значення визначення рівня HbA1c у пацієнтів з МI у клінічній практиці шляхом аналізу зв'язку рівня HbA1c з демографрічними показниками, тяжкістю MI, судинними фракторами ризику, періодом, підтипом та результатами лікування МI.

\section{МАТЕРІАЛИ ТА МЕТОДИ}

Дослідження проведене в Інсультному центрі (ІЦ) - відділенні багатопрофільної лікарні (Медичний центр «Універсальна клініка «Оберіг»). Структура і процеси в ІЦ відповідають сучасним галузевим стандартам і принципам функціонування інтегрованого інсультного блоку: з пацієнтами працюе мультидисциплінарна команда фахівців, що включае лікарів-неврологів та анестезіологів, медичних сестер зі спеціальною підготовкою з інсульту, фізичних терапевтів, ерготерапевтів, логопедів та нейропсихолога; медична допомога надається у відповідності до протоколів, що були розроблені на основі адаптованих вітчизняних та провідних закордонних клінічних настанов; ретельне обстеження з визначенням ймовірної етіології (підтипу) МI; рання комплексна вторинна профілактика; початок міждисциплінарної реабілітації впродовж 48 годин після госпіталізації і достатній об'єм реабілітаційної протягом усього періоду перебування. В усіх пацієнтів були проведені повний неврологічний огляд з оцінюванням за допомогою набору інсультних шкал після госпіталізації та перед випискою з ІЦ і необхідні додаткові дослідження, що включали нейровізуалізацію (комп'ютерна або магнітно-резонансна томографія головного мозку), візуалізацію церебральних судин (комп'ютерна або магнітно-резонансна ангіографія), трансторакальну ехокардіографрію, реєстрацію ЕКГ, холтерівський моніторинг серцевого ритму протягом 24-72 год. Усі паціенти були оглянуті кардіологом, а пацієнти з ознаками порушень вуглеводного обміну чи іншими ендокринними розладами отримали консультацію ендокринолога. Лабораторні дослідження виконувались у сертифікованій лікарняній клініко-діагностичній лабораторії. Рівень НbA1с визначався шляхом аналізу у гемолізованій цільній крові на біохімічному автоматичному аналізаторі «Cobas Integra 400 plus» імунотурбідіметричним методом (сертифікований NGSP та стандартизований за методикою Diabetes Control and Complications Trial - DCCT). Критеріями включення у дослідження були клінічний діагноз МI, верифікований за допомогою нейровізуалізації, стаціонарне лікування в ІЦ тривалістю не менше 3 діб у період між лютим 2010 року та вереснем 2018 року, наявність результатів оцінювання за основними інсультними шкалами та даних щодо рівня HbA1c. Були виключені з дослідження паціенти, які померли протягом стаціонарного лікування, а також пацієнти, які мали субарахноїдальний крововилив внаслідок розриву аневризми 
або вкрай тяжкі супутні захворювання, що істотно впливали на результати лікування (пізня стадія злоякісного новоутворення, термінальна ниркова недостатність, гематологічні захворювання, незрощені переломи кісток, кахексія, сепсис тощо).

Визначений набір даних про кожного з пацієнтів був зібраний проспективно і внесений до спеціально створеної бази даних. Показники включали вік, стать, тип та підтип МI, оцінки тяжкості неврологічного дефіциту за інсультною шкалою Національних інститутів здоров'я (National Institutes of Health Stroke Scale - NIHSS), ступеня обмежень повсякденної життедіяльності за допомогою індексу Бартел та загального результату лікування МI за допомогою модифікованої шкали Ренкіна (мШР). На основі клініко-інструментальних та лабораторних показників усі пацієнти були поділені на два типи МI (ішемічні та геморагічні), а пацієнти з ішемічними MI відповідно до найбільш ймовірної причини ураження мозку були поділені на чотири основні етіопатогенетичні підтипи: атеросклеротичний, кардіоемболічний, лакунарний та інший (інша відома чи невідома етіологія). Діагноз ЦД або предіабету підтверджувався чи вперше встановлювався ендокринологом, згідно з сучасними діагностичними критеріями, а цільовим рівнем $\mathrm{HbA1c}$ у пацієнтів з ЦД вважали < 7,0\% [13]. Під ожирінням, відповідно до рекомендацій Всесвітньої організації охорони здоров'я, розуміли індекс маси тіла $\geq 30,0$ кг/м ${ }^{2}$ [14]. Наявність дисліпідемії констатували у разі виявлення у медичній документації чи після госпіталізації в ІЦ рівня загального холестерину > 5,2 ммоль/л та/або рівня холестерину ліпопротеїнів низької щільності >2,6 ммоль/л [15]. Періоди MI в залежності від часу, що минув 3 ймовірного моменту появи перших його проявів до госпіталізації в ІЦ, поділяли на найгостріший (0-24 години), гострий (1-7 діб), ранній підгострий (з 8-го по 90-й день), пізній підгострий (з 91-го по 180 день) та віддалений (пізніше 180 дня) [16]. Зважаючи на дослідження пацієнтів у різні періоди MI, окремі показники глікемії не вносились в базу даних і не були включені до аналізу.

Категоріальні змінні виражені через частоту та відсотки. Змінні, розподіл яких не відповідав закону нормального розподілу (за критерієм Шапіро-Уілка), відображені за допомогою медіани та міжквартильного інтервалу (MКI) між 1-м та 3-м квартилями (25-м та 75-м персентілями). Для порівняння кількісних показників двох групах використовувався непараметричний критерій Манна-Уітні (Mann-Whitney), для порівняння більше ніж двох груп використовувався критерій Краскела-Уолліса (Kruscal-Wallis) та критерій множинних порівнянь Данна (Dunn). Для оцінки кореляції використовували коефіцієнт рангової кореляції Спірмена (Spearman). Для аналізу якісних ознак використовувався критерій хі-квадрат (chisquare). Поріг статистичної значущості був встановлений на рівні 0,05. Статистичний аналіз результатів дослідження проводився з використанням пакету MedCalc v. 19.1 (MedCalc Software Inc, Broekstraat, Belgium, 1993-2019).

\section{РЕЗУЛЬТАТИ ТА ЇХ ОБГОВОРЕННЯ}

У вибірку дослідження були включені 524 пацієнти (43,4\% жінок). Вік пацієнтів був від 30,7 років до 95,7 років (медіана 67,3 року, MКI 59,3-75,5). Загальна початкова оцінка тяжкості MI за NIHSS після госпіталізації коливалась від 0 до 39 балів (медіана 11 балів, MКI 6-18). При цьому 117 (22,3\%) пацієнтів поступили у найгострішому періоді, 120 (23,0\%) - у гострому, 121 (23,2\%) - з 8-го до 30-го дня, 67 (12,7\%) з 31-го до 90-го дня, 29 (5,5\%) - у пізньому підгострому періоді та 70 (13,3\%) - у віддаленому (хронічному) періоді захворювання. В учасників дослідження була висока розповсюдженість судинних фракторів ризику: 453 (86,5\%) 3 них страждали на артеріальну гіпертензію, у 215 (41,1\%) була виявлена дисліпідемія, 129 (24,7\%) курили, у 142 (27,1\%) МІ був повторним. У 175 (33,4\%) пацієнтів діагноз ЦД (як правило, ЦД 2 типу) був встановлений до госпіталізації в ІЦ, тоді як у 22 (4,2\%) осіб діагноз ЦД 2 типу 
був вперше встановлений під час лікування в ІЦ. Отже частота ЦД у нашій вибірці паціентів з МІ становила 37,6\%. У паціентів з ЦД медіана НbA1c склала 6,90\% (МКI $6,08-8,34)$, а у паціентів без ЦД в анамнезі - 5,57\% (МКІ 5,26-5,87), і ці відмінності були значущими (р < 0,001). У $180(34,4 \%)$ паціентів без ЦД в анамнезі рівень $\mathrm{HbA1c}$ був від $5,71 \%$ до $6,49 \%$, отже у них був діагностований предіабет. Серед 175 паціентів з ЦД в анамнезі у 89 (51\%) рівень HbA1c після госпіталізації в ІЦ відповідав цільовому рівню $(<7,0 \%), 36$ (21\%) учасників дослідження мали показники НbA1c від 7,0\% до $8,0 \%$, а у 50 (28\%) пацієнтів — рівень HbA1c перевищував 8,0\%, що свідчило про хронічну гіперглікемію і недостатній контроль ЦД. Рівень HbA1c вище 8,0\% зокрема був виявлений у $13 \%$ паціентів, які були госпіталізовані у пізньому підгострому періоді, та у $6 \%$ пацієнтів, які поступили в ІЦ у віддаленому (хронічному) періоді MI. Значущих асоціацій між рівнем HbA1c та наявністю артеріальної гіпертензії або дисліпідемії у учасників нашого дослідження не було ( $p=0,135$ та $p=0,100$ відповідно). Не виявлено зв'язку рівня $\mathrm{HbA1c}$ 3 віком паціентів (показник кореляції Спірмена не відрізняеться від $0, \mathrm{p}=0,974$ ) У жінок медіана HbA1с становила 5,80\% (МКI 5,39-6,39), у чоловіків - 5,76\% (МКI $5,40-6,33)$, отже статистично значущих від- мінностей за цим показником в залежності від статі учасників дослідження не виявлено $(\mathrm{p}=0,65)$. Не було також відмінностей за рівнем HbA1c у паціентів з першим у житті чи повторним MI ( $p=0,633)$, а також в залежності від наявності чи відсутності фібриляції пересердь $(\mathrm{p}=0,438)$ чи куріння $(\mathrm{p}=0,759)$.

Водночас в учасників дослідження був виявлений статистично значущий $(\mathrm{p}<0,001)$ зв'язок між рівнем HbA1c та ожирінням: у паціентів з ожирінням рівень $\mathrm{HbA1c}$ (медіана 5,98\%, МКI 5,5-6,98) виявився вищим, ніж у пацієнтів без ожиріння (медіана 5,7\%, MКI 5,36-6,13).

При визначенні типу та підтипу МI у 81 $(15,4 \%)$ паціента був діагностований геморагічний MI (BMК), а у $443(84,6 \%)$ - ішемічний МI (інфаркт головного мозку). Серед паціентів з ішемічним МІ ЦД (включно 3 вперше виявленим) був діагностований у 181 (40,9\%), а серед пацієнтів з ВМК у 16 (19,8\%), і ця різниця була статистично значущою ( $<0,001)$. Пацієнти 3 ішемічним MI з урахуванням ймовірної його етіології були розподілені наступним чином: 184 (41,5\%) віднесені до атеросклеротичного, 204 (46,1\%) - до кардіоемболічного, 32 (7,2\%) - до лакунарного, 23 (5,2\%) до іншого підтипів. Дані щодо рівеня $\mathrm{HbA1c}$ у паціентів з різними типами та підтипами MI наведено у табл.

\section{Показники глікозильованого гемоглобіну у паціентів з різними типами та підтипами мозкового інсульту}

\begin{tabular}{c|c|c|c|c|c|c}
\hline Тип та підтип МI & $\mathbf{N}$ & Мінімум & $\begin{array}{c}\text { 1-й } \\
\text { квартиль }\end{array}$ & Медіана & $\begin{array}{c}\text { 3-й } \\
\text { квартиль }\end{array}$ & $\begin{array}{c}\text { Макси- } \\
\text { мум }\end{array}$ \\
\hline Ішемічний & 443 & 3,53 & 5,47 & 5,84 & 6,48 & 12,97 \\
\hline атеросклеротичний & 184 & 4,20 & 5,54 & $5,91^{*}$ & 7,03 & 12,97 \\
\hline кардіоемболічний & 204 & 3,53 & 5,45 & 5,81 & 6,28 & 12,23 \\
\hline лакунарний & 32 & 4,14 & 5,46 & 5,89 & 7,71 & 11,16 \\
\hline інший & 23 & 4,33 & 5,18 & 5,56 & 5,94 & 12,44 \\
\hline Геморагічний (ВМК) & 81 & 2,78 & 5,13 & $5,50^{\dagger}$ & 5,92 & 9,99 \\
\hline
\end{tabular}

\section{Прилітки.}

ВМК — внутрішньомозковий крововилив;

MI - мозковий інсульт.

$\dagger$ - медіана HbA1с у паціентів з ВМК е нижчою, ніж у пацієнтів з ішемічним MI (p < 0,001).

* - медіана HbA1c при атеросклеротичному підтипі ішемічного МI є вищою, ніж при іншому його підтипі $(\mathrm{p}<0,05)$. 
Як видно з таблиці, у паціентів з ВМК медіана HbA1c була нижчою, ніж у паціентів з ішемічним MI (5,50\% та 5,84\% відповідно), і ці відмінності досягли рівня статистичної значущості $(\mathrm{p}<0,001)$. Водночас медіана НbA1c при атеросклеротичному підтипі ішемічного МІ була вищою, ніж при решті його підтипів, але рівня статистичної значущості $(\mathrm{p}<0,05)$ ці відмінності досягли лише тоді, коли пацієнт був віднесений до іншого підтипу ішемічного MI. Показники HbA1c не мали статистично значущого зв'язку ані з початковою тяжкістю MI, яку відображувала загальна оцінка за NIHSS після госпіталізації в IЦ $(p=0,68)$, ані з функціональним станом після лікування в ІЦ, яку відображувала загальна оцінка повсякденної життедіяльності за індексом Бартел $(\mathrm{p}=0,131)$. Також не виявлено зв'язку між рівнем НbA1c та періодом MI, коли пацієнт був госпіталізований в ІЦ $(p=0,58)$. Разом з тим, загальний результат лікування МI за мШР залежав від початкового рівня глікогемоглобіну: вищий початковий рівень НbA1с асоціювався з вищим рівнем залежності від сторонньої допомоги, який відображуе оцінку за мШР перед випискою з ІЦ ( $<<0,001)$. Таким чином, у цьому ретроспективному обсерваційному дослідженні паціентів з МI, які перебували на стаціонарному лікуванні в ІЦ у різні періоди захворювання (від гострого до віддаленого) та були обстежені у відповідності до сучасних галузевих стандартів, ми вивчили рівень HbA1c та проаналізували його зв'язок з віком та статтю пацієнтів, їх судинними факторами ризику, періодом захворювання, періодом та тяжкістю MI, а також результатами його лікування в ІЦ.

Розповсюдженість ЦД, включно з вперше виявленим під час лікування в ІЦ, у нашій вибірці була високою (майже $38 \%$ ), і цей показник е вищим за частоту ЦД у більшості інших досліджень паціентів з МI. У великому міжнародному дослідженні ЦД, ознакою якого вважали рівень $\mathrm{HbA1c} \geq 6,5 \%$, мали 26\% пацієнтів з гострим МI [17]. В інших дослідженнях частота ЦД серед пацієнтів з гострим МІ варіювала від 13\% до 33\%, що частково пояснюються використанням різних критеріїв для діагностики ЦД [4].
Крім того, більш ніж у третини наших паціентів без ЦД в анамнезі був діагностований предіабет, що свідчить про дуже високу частоту порушень обміну глюкози у паціентів з МІ. Відмінності з результатами інших досліджень можуть бути обумовлені тим, що решта досліджень була проведена раніше й у популяціях країн 3 високим рівнем доходів населення, де розповсюдженість ЦД можу бути нижчою, ніж у країнах Східної Європи, включно з Україною. Така висока частота порушень обміну глюкози у паціентів з МI, на нашу думку, вказуе на важливу роль ендокринолога як члена мультидисциплінарної команди яка надає допомогу пацієнтам з MI.

Наше дослідження підтверджуе, що визначення рівня HbA1c е відносно простим, надійним та результативним способом виявлення ЦД та оцінки рівня контролю глікемії у пацієнтів з МІ незалежно від періоду захворювання, тяжкості неврологічного дефіциту та наявності ускладнень. Визначення рівня HbA1c дало можливість вперше встановити діагноз ЦД більш ніж у 4\% наших паціентів та констатувати недостатній контроль глікемії у 49\% паціентів з ЦД (HbA1c > 7,0\%), що було важливою передумовою швидкого початку чи збільшення інтенсивності лікування ЦД. Інші дослідники також дійшли висновку, що одноразове дослідження HbA1c е надійним та зручним способом скринінгу щодо ЦД в умовах лікарні [11].

Вищий рівень HbA1c у паціентів з ЦД у порівнянні з паціентами без ЦД виглядає цілком зрозумілим, але той факт, що у $28 \%$ учасників нашого дослідження рівень HbA1c був вище 8,0\% переконливо свідчить про те, що контроль ЦД діабету у них не можна вважати достатнім. Відповідно, майже у третині випадків не були вжиті заходи, необхідні та достатні для ефективної профілактики MI та інших ускладнень ЦД. У попередніх дослідженнях було продемонстровано, що рівень HbA1с може бути незалежним фрактором ризику МI [18]. Відтак, періодичне визначення рівня $\mathrm{HbAlc}$ може сприяти підвищенню ефективності профрілактики MI за рахунок оптимізації контролю глікемії. 
Причини вдвічі більшої частоти ЦД та значно вищого рівня HbA1c у пацієнтів 3 ішемічним MI у порівнянні з пацієнтами ВМК не до кінця зрозумілі. Їх частково можна пояснити прямим зв'язком між HbA1c та ЦД. Як зазначають експерти, паціенти з ЦД мають особливу схильність до розвитку метаболічного синдрому та/або діабетичної нефропатії, і на момент розвитку MI у більшості паціентів з ЦД має місце не тільки артеріальна гіпертензія, але й значна дисліпідемія, що сприяють прогресуючим атеросклеротичним ураженням церебральних судин, які мають більш тісний зв'язок з ішемічним MI [5]. Таке ж саме пояснення, ймовірно, має дещо вищий рівень HbA1c, виявлений нами при атеросклеротичному підтипі ішемічного МІ у порівнянні з іншими його підтипами.

Результати досліджень прогностичного впливу рівня НbA1c при МI є суперечливими. У нашому дослідженні не було виявлено прямого і незалежного впливу рівня HbA1c на базову повсякденну життедіяльність паціентів з МІ після лікування в ІЦ, яку оцінювали за допомогою індексу Бартел. Деякі дослідники повідомляють, що вищий рівень HbA1c е предиктором як вищої летальності, так і поганого функціонального стану після МІ у пацієнтів з ЦД чи без ЦД [6]. Ми також продемонстрували, що е тенденція до погіршення загального результату лікування (підсумкова оцінка за мШР) у разі вищого рівня HbA1c на момент госпіталізації незалежно від наявності чи відсутності ЦД в анамнезі, що також може вказувати на важливість періодичного визначення рівня HbA1c та кращого контролю глікемії у разі порушень обміну глюкози. Раніше вже була продемонстро- вана важливість кращого контролю глікемії перед МI для поліпшення результатів його лікування [19]. Wang et al. нещодавно повідомили, що вищий рівень $\mathrm{HbA1c}$ асоціюеться з гіршим функціональним станом у пацієнтів з гострим ішемічним МI і наголосили на важливості більш суворого контролю глікемії у паціентів з ЦД та високим ризиком MI [9]. Несприятливий вплив вищого рівня HbA1c на результати лікування MI може бути обумовлений кількома чинниками. По-перше, стійка гіперглікемія після МІ може сприяти збільшенню тяжкості ураження мозку і розміру вогнища. По-друге, хронічна гіперглікемія викликае зміни у дрібних церебральних судинах та білій речовині мозку (лейкоарейоз, лакуни), які можуть перешкоджати відновленню мозку після МІ. Зрештою, хронічна гіперглікемія асоціюеться з комплексом патологічних процесів (оксидантний стрес, утворення вільних радикалів, дисфункцію ендотелію, протромботичні стани, тощо), які можуть спричиняти вторинне ушкодження паренхіми головного мозку та збільшувати неврологічний дефіцит [20].

Отже, результати нашого дослідження свідчать про можливість та практичне значення визначення рівня HbA1c у пацієнтів з МІ у клінічній практиці. Це сприяе швидкій діагностиці ЦД чи предіабету та оптимізації лікувальних заходів до виписки пацієнта з лікарні. Несприятливий вплив вищого рівня HbA1c на загальний результат лікування МI вказуе на доцільність частішого визначення цього показника у пацієнтів з ЦД з метою як зменшення ризику виникнення МI, так і поліпшення прогнозу при MI.

\section{ВИСНОВКИ}

1. Визначення рівня HbA1c у пацієнтів з МI у клінічній практиці е доступним і надійним способом виявлення ЦД та оцінювання ступеня контролю глікемії як до, так і після перенесеного МI.

2. Зважаючи на високу частоту порушень обміну глюкози (майже у 40\% пацієнтів був діагностований ЦД, ще у майже $35 \%$ - предіабет), лікар-ендокринолог відіграе важливу роль у наданні допомоги паціентам з МI.

3. У значної частини паціентів з МІ та ЦД у різні періоди MI рівень НbA1c перевищував 8,0\%, що вказуе на необхідність кращого контролю глікемії, який е важливою складовою профілактики МІ та інших ускладнень ЦД. 


\section{ЛITЕРАТУРА \\ (REFERENCES)}

1. Brainin M, Feigin VL, Norrving B, et al. Lancet Neurol 2020; 19(6): 487-488. doi: 10.1016/S1474-4422(20)30141-1.

2. IDF Diabetes Atlas, 9th ed. Brussels: International Diabetes Federation, 2019, available at: https://www. diabetesatlas.org/en/.

3. Phipps MS, Jastreboff AM, Furie K, Kernan WN. Curr Diab Rep 2012; 12(3): 314-323. doi: 10.1007/s11892-0120271-x.

4. Lau LH, Lew J, Borschmann K, et al. J Diabetes Invest 2019; 10(3): 780-792. doi: 10.1111/jdi.12932.

5. Hill MD. Handb Clin Neurol 2014; 126: 167-174. doi: 10.1016/B978-0-444-53480-4.00012-6.

6. Lei C, Wu B, Liu M, Chen Y. J Clin Neurosci 2015; 22(3): 498-503. doi: 10.1016/j.jocn.2014.08.030.

7. Tuttolomondo A, Pinto A, Salemi G, et al. Nutr Metab Cardiovasc Dis 2008; 18(2): 152-157. doi: 10.1016/j.numecd.2007.02.003.

8. Zhao L, Wang L, Lu M, et al. Medicine (Baltimore) 2019; 98(31): e16723. doi: 10.1097/MD.0000000000016723.

9. Wang H, Cheng Y, Chen S, et al. J Stroke Cerebrovasc Dis 2019; 28(2): 470-476. doi: 10.1016/j.jstrokecerebrovasdis.2018.10.026.

10. d'Emden MC, Shaw JE, Colman PG, et al. Med J Aust 2012; 197(4): 220-221. doi: 10.5694/mja12.10988.

11. Sequeira IR, Poppitt SD. Insights Nutr Metabol 2017; 1(1): $11-20$
12. Huisa BN, Roy G, Kawano J, Schrader R. J Stroke Cerebrovasc Dis 2013; 22(8): e564-e567. doi: 10.1016/j. jstrokecerebrovasdis.2013.06.023.

13. American Diabetes Association. Diabetes Care 2020; 43(1): S14-S31. doi: 10.2337/dc20-S002.

14. World Health Organization. Obesity and overweight, Geneva, 2020, available at: https://www.who.int/newsroom/fact-sheets/detail/obesity-and-overweight.

15. Halawani FMA, Alahmari SZ, Asiri AD, et al. Arch Pharma Pract 2019;10(4): 67-70, available at: https:// archivepp.com/storage/models/article/3m8LcQ1PlYrNo aphvNC8ZNGzdft178hh5fVw6vo1jf3BbiSBFmqsqfFCwb 7q/diagnosis-and-management-of-dyslipidemia.pdf).

16. Bernhardt J, Hayward KS, Kwakkel G, et al. Int J Stroke 2017; 12(5): 444-450. doi: 10.1177/1747493017711816.

17. O'Donnell MJ, Chin SL, Rangarajan S, et al. Lancet 2016; 388. doi: 10.1016/S0140-6736(16)30506-2.

18. Selvin E, Coresh J, Shahar E, et al. Lancet Neurol 2005; 4(12): 821-826. doi: 10.1016/S1474-4422(05)70227-1.

19. Luitse MJ, Velthuis BK, Kappelle LJ, et al. Int J Stroke 2017; 12(2): 180-186. doi: 10.1177/1747493016676619.

20. Tamura Y, Araki A. Geriatr Gerontol Int 2015; 15(1): 3442. doi: 10.1111/ggi.12666. 


\title{
РОЛЬ ВИЗНАЧЕННЯ ГЛІКОЗИЛЬОВАНОГО ГЕМОГЛОБІНУ У ПАЦІЄНТІВ З МОЗКОВИМ ІНСУЛЬТОМ \\ Фломін Ю. В. ${ }^{1}$ Гур'янов В. Г. ${ }^{2}$, Соколова Л. К. ${ }^{3}$, Таран Л. Ф. ${ }^{1}$, Соколова Л. І. ${ }^{2}$ \\ ${ }^{1}$ Медичний иентр «Універсальна клініка "Оберіг»", м. Київ, Україна; \\ ${ }^{2}$ Національний медичний університет ім. О. О. Боголольия МОЗ Украӥни, м. Київ, Україна; \\ ${ }^{3}$ Інститут ендокринологї та обміну речовин ім. В. П. Комісаренка НАМН Украӥни, м. Київ, Украӥна \\ flomin.yuriy@gmail.com
}

Мозковий інсульт (MI) та цукровий діабет (ЦД) е розповсюдженими неінфекційними захворюваннями, які мають багаторівневий взаємозв'язок. Визначення рівня глікозильованого гемоглобіну (HbA1c) е зручним та надійним способом виявлення ЦД та оцінки його контролю, але роль НbА1c при МІ ще остаточно не визначена. Метою дослідження було вивчити можливість та значення визначення рівня HbA1c у пацієнтів з МI у клінічній практиці шляхом аналізу зв'язку рівня НbA1c 3 демографічними показниками, тяжкістю інсульту, судинними факторами ризику, періодом, підтипом та результатами лікування MI.

Матеріал і методи. Проаналізовано дані 524 паціентів (43,4\% жінок) з веріфікованим діагнозом MI, які у 2010-2018 рр. перебували на стаціонарному лікуванні у різні періоди МІ (від найгострішого до віддаленого). В усіх пацієнтів був визначений рівень НbA1c після госпіталізації, а також проведені необхідні додаткові дослідження згідно з галузевими стандартами та оцінювання за шкалами, зокрема за National Institutes of Health Stroke Scale (NIHSS), індексом Бартел та модифікованою шкалою Ренкіна (мШР). Категоріальні змінні відображені як число та проценти. Змінні, розподіл яких відрізнявся від нормального, відображені через медіану та міжквартильний інтервал (МКI). Статистичний аналіз даних проводився у MedCalc v. 19.1.

Результати. Вік учасників дослідження був від 30,7 років до 95,7 років (Me 67,3, MКI 59,3-75,5). У 81 (15,4\%) паціента діагностований геморагічний MI, у 443 (84,6\%) пацієнтів - ішемічний MI. Загальна початкова оцінка за NIHSS після госпіталізації коливалась від 0 до 39 балів (Ме 11, MКI 6-18). У вибірці документована висока частота судинних фракторів ризику: 86,5\% страждали на артеріальну гіпертензію, 41,1\% - на дисліпідемію, 24,7\% курили, у 27,1\% МІ був повторним. Серед учасників 33,4\% мали ЦД в анамнезі, тоді як у 4,2\% осіб ЦД 2 типу був виявлений у нас вперше. Крім того, у 34,4\% пацієнтів був діагностований предіабет. Серед пацієнтів з ЦД в анамнезі показники HbA1c на момент госпіталізації у $21 \%$ були від $7,0 \%$ до 8,0\%, а у $28 \%$ - вище $8,0 \%$. Початковий НbA1c не корелював з демографічними показниками, судинними фокторами ризику (крім ЦД та ожиріння), початковою тяжкістю інсульту та рівнем повсякденної життедіяльності після лікування. Проте вищий рівень HbA1c мав значущі (p < 0,05) асоціації з ішемічним MI, його атеросклеротичним підтипом та гіршим загальним результатом лікування МI (підсумкова оцінка за мШР).

Висновки. Визначення HbA1c у стаціонарних пацієнтів з MI у клінічній практиці виглядає можливим і доцільним, оскільки воно дає змогу діагностувати ЦД чи предіабет та призначити необхідне лікування до виписки з лікарні. Частіше визначення НbA1c у паціентів з ЦД може сприяти як ефективнішій профілактиці МI, так і поліпшенню прогнозу у разі виникнення гострого МI.

Ключові слова: мозковий інсульт, цукровий діабет, глікозильований гемоглобін, глікемія, прогноз.

\section{ROLE OF GLYCOSYLATED HEMOGLOBIN TESTING IN PATIENTS WITH CEREBRAL STROKE}

\author{
Flomin Y. V. ${ }^{1}$, Gurianov V. G. ${ }^{2}$, Sokolova L. K. ${ }^{3}$, \\ Taran L. F. ${ }^{1}$, Sokolova L. I. \\ ${ }^{1}$ Medical center "Universal clinic "Oberig", Kyiv, Ukraine; \\ ${ }^{2}$ Bogomolets National Medical University, Ministry of Health of Ukraine, \\ Kyiv, Ukraine; \\ ${ }^{3}$ Komisarenko Institute of Endocrinology and Metabolism, \\ National Academy of Medical Sciences of Ukraine, \\ Kiev, Ukraine \\ flomin.yuriy@gmail.com
}

Background. Cerebral stroke (CS) and diabetes mellitus (DM) are common noncommunicable diseases with multifaceted interactions. The glycosylated hemoglobin (HbA1c) testing is a convenient and reliable method for detecting DM and evaluating its control, but the role of HbA1c in CS is not well established. The aim of the study was to explore feasibility and significance of HbA1c testing among CS in-patients in clinical practice by studying the relationship between the HbA1c level and demographic data, CS severity, vascular risk factors, CS period, its subtype and outcome. 
Material and methods. Data of 524 inpatients (43.4\% women) with a verified CS, who were admitted 2010 through 2018 in various CS periods (from hyperacute to chronic) were analyzed. All patients had an HbA1c level determined upon admission, and underwent all necessary ancillary investigations according to current guidelines in addition to assessment with relevant scales, such as the National Institutes of Health Stroke Scale (NIHSS), Bartel index and modified Rankin scale (mRS). Categorical variables are shown as numbers and percentages. Variables with abnormal distribution were expressed as median $(\mathrm{Me})$ and the interquartile range (IQR). Statistical analysis of the data was carried out in MedCalc v. 19.1 package.

Results. Participants' age ranged from 30.7 years to 95.7 years (Me 67.3, IQR 59.3-75.5). In 81 (15.4\%) the diagnosis of hemorrhagic CS was made, whereas 443 (84.6\%) subjects had ischemic CS. The baseline NIHSS score ranged from 0 to 39 points (Me 11, IQR 6-18). In our sample, high frequency of vascular risk factors was documented: $86.5 \%$ suffered from arterial hypertension, $41.1 \%$ had dyslipidemia, $24.7 \%$ were current smokers, and $27.1 \%$ had recurrent CS. Among the participants, $33.4 \%$ had a history of DM, while in $4.2 \%$ type 2 diabetes was detected de novo. Apart from that, prediabetes was diagnosed in $34.4 \%$ of the subjects. Among patients with a history of DM, $21 \%$ had initial HbA1c $7.0 \%$ to $8.0 \%$, and $28 \%$ had HbA1c over $8.0 \%$. Baseline HbA1c level did not correlate with demographic characteristics, vascular risk factors (except for DM and obesity), baseline stroke severity, and activities of daily living (Barthel Index score) at discharge. However, a higher HbA1c level was significantly $(\mathrm{p}<0.05)$ associated with ischemic CS, its atherosclerotic subtype, and the worse global CS outcome (final mRS score).

Conclusions. HbA1c testing in inpatients with CS in clinical practice appears feasible and justified, since it allows detecting DM or prediabetes as well as prescribing the necessary treatment prior to discharge. More frequent $\mathrm{HbA1c}$ testing in patients with DM can contribute to both more effective CS prevention and an improved prognosis in the case of acute CS.

Keywords: cerebral stroke, diabetes mellitus, glycosylated hemoglobin, glycemia, prognosis. 